Christian FARgeOT ${ }^{1}$

Nolwenn DROUET-HOGUET ${ }^{2}$

Sébastien LE BEL ${ }^{1}$

${ }^{1}$ Cirad

UPR Forêts et Sociétés

Campus International de Baillarguet 34398 Montpellier Cedex 5

France

2 Practical Wildlife

82 rue Anatole France

38100 Grenoble

France

\section{The role of bushmeat in urban household consumption: Insights from Bangui, the capital city of the Central African Republic}

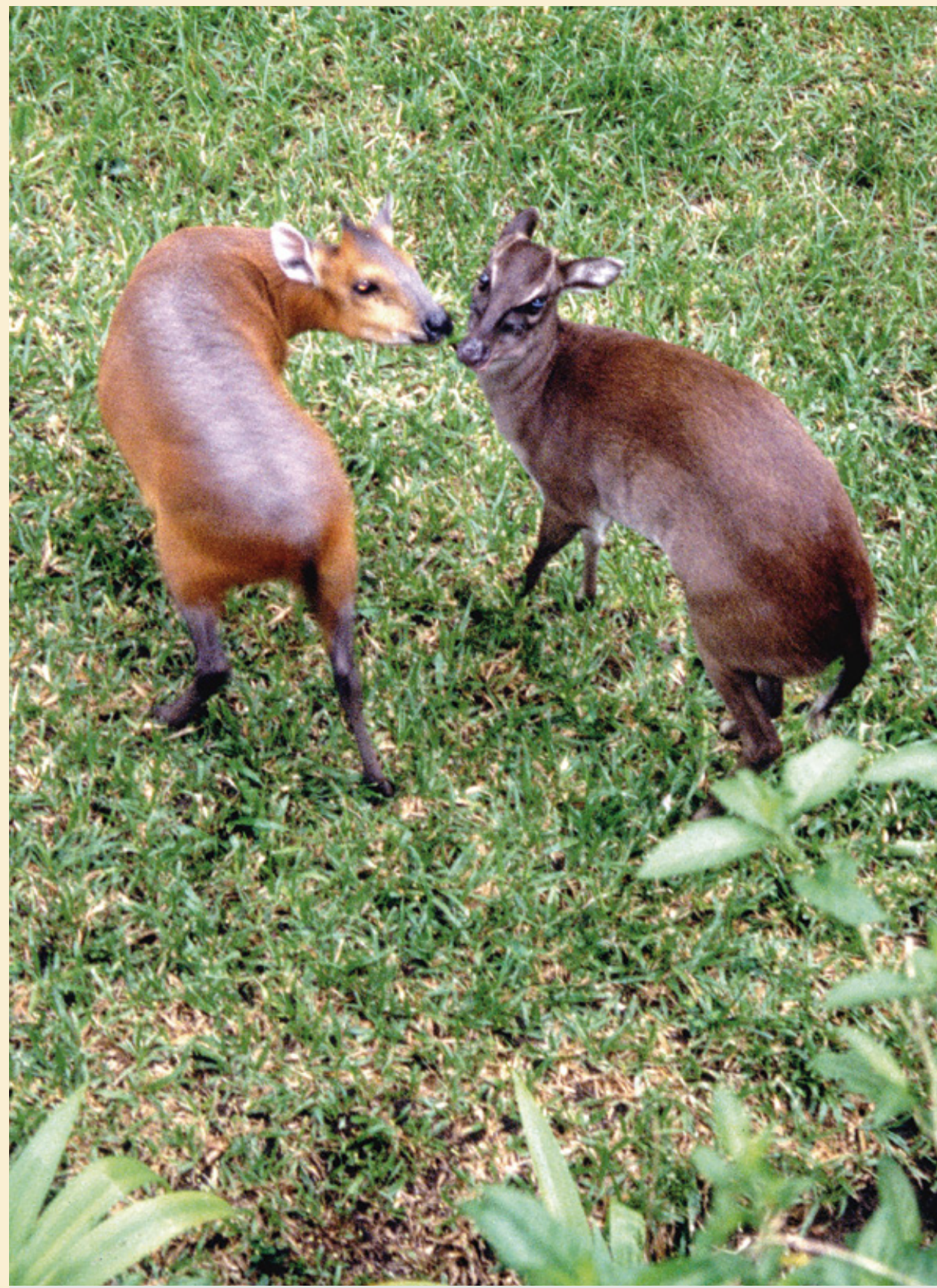

Photo 1.

Blue duiker (Philotomba monticola).

Photo D. Louppe. 


\section{Fargeot, N. Drouet-Hoguet, S. LE BEL}

\section{RÉSUMÉ}

\section{IMPORTANCE DE LA VIANDE DE BROUSSE DANS LA CONSOMMATION DES MÉNAGES URBAINS : ENQUÊTE À BANGUI, CAPITALE DE LA RÉPUBLIQUE CENTRAFRICAINE}

Dans le Bassin du Congo, le gibier fournit une part importante des protéines consommées par les ménages ruraux. Dans un contexte d'urbanisation croissante, une bonne connaissance de la consommation de viande de brousse par les ménages urbains est indispensable, tant pour traiter les questions de sécurité alimentaire que pour développer des stratégies de conservation de la biodiversité. Cet article propose un éclairage sur les modes de consommation de viande de brousse à Bangui, capitale de la République centrafricaine, basé sur une analyse des dépenses des ménages et des prix de marché. Une enquête menée auprès d'environ 4000 ménages associée à un suivi sur trois ans (2005-2008) des prix sur les marchés a permis une estimation de la consommation de viande de brousse et d'autres protéines animales. Les résultats montrent l'existence d'une offre diversifiée de protéines animales sur les marchés de Bangui, issues de gibier et d'animaux domestiques. En termes de composition taxonomique, l'offre de viande de brousse est principalement constituée d'espèces sauvages communes et sédentaires qui résistent bien à la pression de la chasse, tandis que les espèces protégées sont rarement observées. L'enquête sur la consommation des ménages montre que $54 \%$ des repas quotidiens contiennent du bœuf, $35 \%$ du poisson et $19 \%$ de la viande de brousse. La consommation de poisson et de viande de brousse diminue en saison des pluies et la consommation de chenilles augmente. Quant aux prix, les viandes fumées (gibier, poisson) sont moins chères que toutes les protéines animales fraîches à l'exception des chenilles. La consommation de protéines animales et de viande de brousse augmente avec les revenus ; les protéines fraîches sont davantage consommées par les ménages aisés alors que la viande de brousse fumée est consommée par les plus pauvres. Si la consommation totale de protéines et de viande de brousse est la plus forte parmi les ménages aisés, la part relative de viande de brousse dans la consommation totale des protéines est la plus forte parmi les ménages pauvres. Globalement, ces résultats confirment l'importance de la viande de brousse dans l'alimentation des citadins, surtout chez les plus pauvres. Cependant, les modes de consommation qui se dégagent indiquent que la viande de brousse est moins appréciée que les autres sources de protéines animales, ce qui pourrait limiter la croissance de sa consommation, notamment en cas de meilleure disponibilité de viandes alternatives et moins chères.

Mots-clés : commerce de viande de brousse, consommation de viande de brousse, sécurité alimentaire, Bangui, République centrafricaine.

\section{ABSTRACT}

\section{THE ROLE OF BUSHMEAT IN URBAN HOUSEHOLD CONSUMPTION: INSIGHTS FROM BANGUI, THE CAPITAL CITY OF THE CENTRAL AFRICAN REPUBLIC}

In the Congo Forest Basin, hunting provides a major source of protein for rural household consumption. In the context of increasing urbanisation, an understanding of bushmeat consumption in urban settings is needed to both address food security issues and design biodiversity conservation strategies. This paper provides insights into bushmeat consumption patterns in Bangui, the capital of the Central African Republic, through an analysis of household expenditures and market prices. A survey of approximately 4,000 households combined with 3 years (2005-2008) of market price monitoring was used to estimate the consumption of bushmeat and alternative proteins. The results showed the presence of a diverse range of animal proteins on the Bangui market, including meat from domestic and wild animals. The taxonomic composition of the bushmeat mainly included common, sedentary wildlife species that are highly resilient to hunting pressure, while protected species were rarely observed. The household consumption survey showed that $54 \%$ of daily meals contained beef, $35 \%$ contained fish and $19 \%$ contained bushmeat. Fish and bushmeat consumption decreased in the rainy season, and caterpillar consumption increased. Smoked proteins (bushmeat, fish), were cheaper than all fresh meat except for caterpillars. The consumption of proteins and bushmeat increased with wealth; fresh proteins were consumed more by wealthy consumers, while smoked bushmeat was consumed by the poorest. Total consumption of protein and bushmeat was highest in rich households, but the relative proportion of bushmeat in the total protein intake was highest for poor households. Overall, the results confirm the importance of bushmeat in the diet of urban consumers, especially in poor households. However, the patterns of consumption suggest that bushmeat is less popular than alternatives, which may potentially limit an increase in bushmeat consumption, particularly if cheaper, alternative meat can be made available.

Keywords: bushmeat trade, bushmeat consumption, food security, Bangui, Central African Republic
RESUMEN

\author{
LA CARNE SILVESTRE EN EL CONSUMO DE LOS \\ HOGARES: ENCUESTA EN BANGUI, CAPITAL \\ DE DE LA REPÚBLICA CENTROAFRICANA
}

La caza proporciona una importante parte de las proteínas que consumen los hogares rurales de la cuenca del Congo. En un marco de creciente urbanización, es necesario conocer bien el consumo de carne silvestre por los hogares urbanos, tanto para abordar los problemas de seguridad alimentaria como para desarrollar estrategias de conservación de la biodiversidad. Este artículo ofrece información sobre los hábitos de consumo de carne silvestre en Bangui, capital de la República Centroafricana, a través de un análisis de gastos de los hogares y de precios de mercado. La realización de una encuesta en aproximadamente 4000 hogares, combinada con un seguimiento durante 3 años (2005-2008) de los precios en los mercados, permitieron estimar el consumo de carne silvestre y de otras proteínas animales. Los resultados muestran la existencia de una oferta variada de proteínas animales, provenientes de animales silvestres y domésticos, en los mercados de Bangui. La composición taxonómica de la carne de caza incluye principalmente especies silvestres comunes y sedentarias altamente resistentes a la presión cinegética, mientras que la presencia de especies protegidas es bastante escasa. La encuesta de consumo de los hogares muestra que el $54 \%$ de las comidas diarias contiene carne de vacuno, el 35\% pescado y el $19 \%$ carne de caza. El consumo de pescado y de carne de caza disminuye en la estación de lluvias, aumentando el consumo de orugas. Con respecto a los precios, los ahumados (carne, pescado) son más baratos que las demás proteínas animales frescas con excepción de las orugas. El consumo de proteínas animales y de carne silvestre aumenta con el nivel de renta: los hogares acomodados comen más proteínas frescas, mientras que los hogares pobres comen más carne silvestre ahumada. El consumo total de proteínas y de carne silvestre es más alto en los hogares acomodados, pero la proporción relativa de carne silvestre en el consumo total de proteínas es mayor en los hogares pobres. En general, estos resultados confirman la importancia de la carne silvestre en la alimentación de los consumidores urbanos, especialmente en los más pobres. Sin embargo, los hábitos de consumo sugieren que la carne silvestre es menos apreciada que las demás fuentes de proteínas animales, esto podría limitar el aumento de su consumo, especialmente si se dispone de carnes alternativas más baratas.

Palabras clave: comercio de carne silvestre, consumo de carne silvestre, seguridad alimentaria, Bangui, República Centroafricana. 


\section{Introduction}

Bushmeat consumption has been deeply ingrained in the African culture for millennia, and it is part of the Congo Forest Basin history. Today, bushmeat still plays a major role in the daily nutrition balance of rural populations. Wild meat consumption is considered to be crucial for food security in central Africa (Fa et al., 2003, 2009; Bennett and Robinson, 2000; Wilkie et al., 2005; FAO, 2006), even if recent Ebola outbreaks are raising questions about the health consequences of consuming bushmeat (Leroy et al., 2004) and its potential impact on urban consumers (CBSNEWS, 2014).

Previously, bushmeat has been placed at the heart of debates after primatologist Rose (1996) used the term "bushmeat crisis" to link the decline of great apes with poaching and to condemn the entire bushmeat supply chain. The bushmeat trade was assumed to involve unsustainable hunting of wildlife, with immediate and significant threats to the conservation of biological diversity in the tropical forest, creating "empty forest" syndrome (Redford, 1992; Bennett, 2008; Harrison, 2011). A growing human population in the region was identified as a key factor in the bushmeat crisis (Bowen-Jones and Pendry, 1999), and this population growth served as a point of argument in favour of a restricted bushmeat trade. In fact, with high urbanization rates in sub-Saharan Africa (Dubresson and Raison, 1998), it is legitimate to question the effect of urban market development on the consumption of bushmeat and its impact on de facto wildlife harvest.

Urban bushmeat consumption has been previously documented in Libreville and Port Gentil, Gabon (Steel, 1994), in Accra, Ghana (Asibey, 1974; Ntiamoa-Baidu, 1987), in the port city of Bata (Fa et al., 1995; Puit, 2003) and in Rio Muni of Equatorial Guinea (East et al., 2005), and more recently in Kisangani (Van Vliet et al., 2012; Colyn et al., 1987) and Kinshasa, Democratic Republic of the Congo (DRC) (Ndona, 2003), and in Brazzaville, Republic of Congo (Mbete et al., 2011). However, the bushmeat trade in the Central African Republic (CAR) is still poorly studied. Initial descriptions of the sector were made in the nineties (Docky, 1987; Peters, 1993; Noss, 1998), followed by studies conducted in the 2000s (Diéval, 2000; Rieu, 2005; Yamalé, 2006).

In this study, we analyse the determinants of urban bushmeat consumption in Bangui, the capital of the CAR with an estimated population of 800,000 inhabitants (Doungoupou, 2005). We examined data from consumption, household expenses, and market surveys in relation to bushmeat and alternative animal proteins. We investigated the relationships between bushmeat consumption, the cultural characteristics of households (religion affiliation, ethnic group), household income, and the prices of the proteins that are found in markets. Recommendations are made for the long-term monitoring of urban markets to develop policies for food supply and biodiversity conservation.

\section{Methods}

\section{Study site}

The study area is Bangui, the capital of CAR. The city lies on the northern bank of the Ubangi River. With an estimated population of 800,000 inhabitants distributed over a land area of 67 square kilometres based on a 2003 census (Doungoupou, 2005), it is the largest city in the country. Several bushmeat markets are present in Bangui (figure 1), offering both wholesale and retail services (Diéval, 2000). The PK-12 market, which is $12 \mathrm{~km}$ north of the city centre, is one of the most important wholesale markets, playing a vital interface between rural and urban districts (Luzietoso, 1999). Towards the city centre are the PK-9 and PK-5 markets. The PK-5 market is associated with smaller retail markets, such as the Kokoro and Mamadou Mbaiki markets (district 3), the Boy Rabe and Combattant markets (district 4 and 8) and the Garangbaka market (district 2). Ouango, a bushmeat market located on the riverside, is unique in that it is a fish market. Located in the old colonial town, the Central market (PK-0) is usually frequented by wealthy customers.

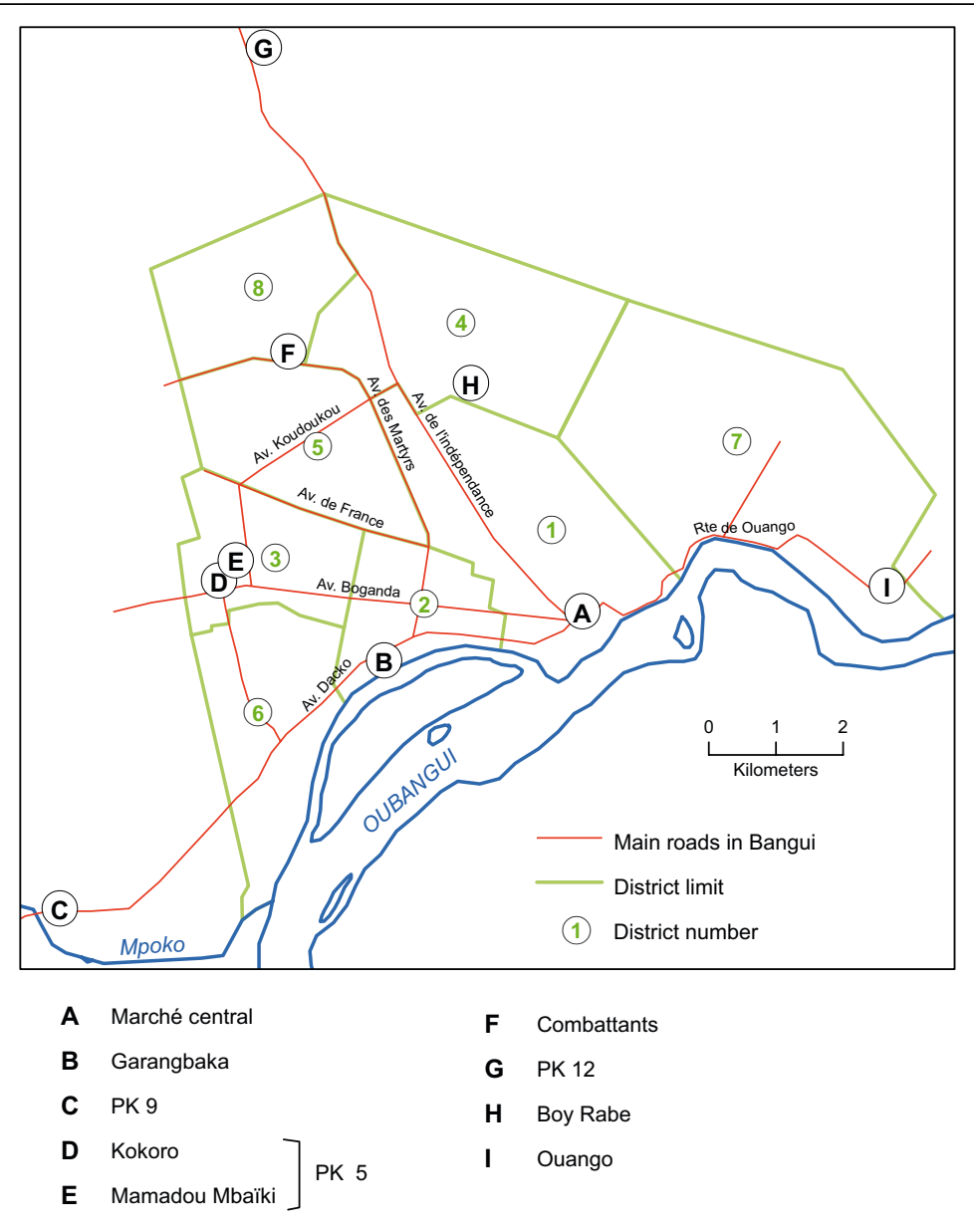

Figure 1.

Map of the study area showing the locations of the main markets (A to I), the main roads (red lines) and Bangui districts (green lines), in Central African Republic. 


\section{Data collection}

The study was conducted over a period of 36 months (June 2005 to June 2008) as part of a French-Central African Project entitled "Projet de Gestion des Terroirs de Chasse Villageoise (PGTCV)". Placed under the authority of the Ministry of the Environment, Water Resources and Forestry of the Central African Republic, the study received all necessary national agreements and authorisations.

Existing legislation on wildlife conservation in CAR (Law No. 84/045 of 2 July, 1984, on the protection of wildlife and hunting regulations in Central African Republic) has been described as no longer reflecting the current reality, as it includes inadequate, overlapping and contradictory texts. Restricting the rights of hunting and trade at a village level (article 36) placed urban bushmeat traders and suppliers in an informal and illegal business category, even though it is locally tolerated by authorities (Fargeot, 2013). For this reason, we remained cautious during our investigation by making it clear to interviewees that the collected data would be confidential. For the long-term monitoring of markets, the investigators were introduced individually to traders to develop mutual confidence. Interviews were conducted either in French or Sango (official language). To study such an informal sector, a multi-approach method described by Weber (1995) with three complementary surveys was implemented.

First, a preliminary survey was conducted in March 2006 (dry season) by 15 investigators in 22 primary schools of the Bangui area to assess the consumption of different sources of protein by urban households. Based on a 24-hour recall method (Université Médicale Virtuelle Francophone, 2011), children aged 9 to 10 years old were asked about the composition of their meals from the previous day and on basic socio-economic information related to their household. Interviewing children from the same classroom ensured social and cultural diversity in the questionnaire responses. To assess the consumption trend during the rainy season, a complementary survey was conducted in August 2006.

The second type of survey was aimed at understanding the role of pricing on the purchase of bushmeat. The prices of available protein sources were assessed mainly based on the PK-5 and PK-12 wholesale markets. To facilitate the comparison of smoked bushmeat with fresh alternative proteins, recorded prices were converted to equivalent fresh biomass prices. Each market was visited daily, 7 days a week, and investigators recorded the selling price, weight of portions on sale and wild species ${ }^{1}$, when identification was possible.

The last survey, conducted in March 2008, addressed household-level consumption of bushmeat in relation to revenue, religion and ethnic affiliation. One thousand households were interviewed for seven consecutive days; consumption was estimated from the daily expenses allocated to the purchase of proteins. Household expenses for meat were estimated by dividing the amount of each food category by the

1 Blue duiker, small-medium herbivores $<15 \mathrm{~kg}$, primate, suid, large herbivore $>50 \mathrm{~kg}$, rodent, caterpillar, divers including snake, bird and insects. Small and medium sized animals were generally sold either in one piece, in half or quarter, while the size and weight of large species varied considerably among markets. prices reported from the market survey. Based on a previous study conducted in Bangui (Doungoupou, 2005), we defined the categories of wealthy and poor households.

\section{Data treatment and analysis}

To compare between fresh and smoked protein sources, it was necessary to convert smoked produce weight (bushmeat and fish) to its protein content equivalent. According to Diéval (2000), $2.5 \mathrm{~kg}$ of fresh blue duiker (Philantomba monticola) meat, including bones, equals $1 \mathrm{~kg}$ of smoked carcass. For fish, calibration trials calculate that $4 \mathrm{~kg}$ of fresh fish is equal to $1 \mathrm{~kg}$ of smoked fish. Comparison of market prices was conducted on a quarterly basis using the average cost of blue duiker as a proxy indicator.

The XLSTAT package, version 2010, was used to analyse the data. Data are presented as the means $\pm S E(n=x x)$. Analyses of variance (ANOVAs) were conducted to test the differences in prices per kilogram among sources of proteins, markets, and season. The same type of analysis was conducted to test the differences in daily individual bushmeat consumption in relation to religion and ethnic influence. Student's t-test was used to test the effects of revenue and wealth on household bushmeat consumption (total, fresh and smoked bushmeat). The null hypothesis between classes was rejected at $p<0.05$. Results with $p<0.001$ were considered highly significant.

\section{Results}

\section{Household protein consumption}

\section{Patterns of urban consumption of protein}

In total, 2,889 children were interviewed, 2,038 during the dry season and 851 during the rainy season. The results demonstrated the importance of animal protein in the diet of the Bangui population, with $84 \%(n=1,652)$ and $87 \%$ $(n=737)$ of the households consuming meat or fish during the dry season and rainy season, respectively. The importance of animal consumption is characterised by a diversity of proteins sources, including wild and domesticated animals (figure 2).

Among the households consuming animal proteins during the dry season $(n=1,652)$, more than half consumed beef (55\%), one-third consumed fish (35\%), and $19 \%$ consumed bushmeat; consumption of other sources of animal protein, aside from eggs (7\%), was less than $5 \%$ (chicken, $4 \%$; shrimp, $4 \%$; canned meat, $4 \%$; pork, $2 \%$; goat, $1 \%$; and caterpillar, $1 \%)$. During the rainy season, the proportion of consumers who reported eating beef was approximately the same ( $48 \%$ ); the proportion of other sources of animal proteins eaten differed, with an increase in consumed caterpillars (22\%) and decreased proportions of fish (19\%) and bushmeat (10\%) (figure 2). Other sources of animal protein were negligible, with $2 \%$ for chicken meat and less than $1 \%$ for other sources (pork, goat, sheep, shrimp and canned meat). 


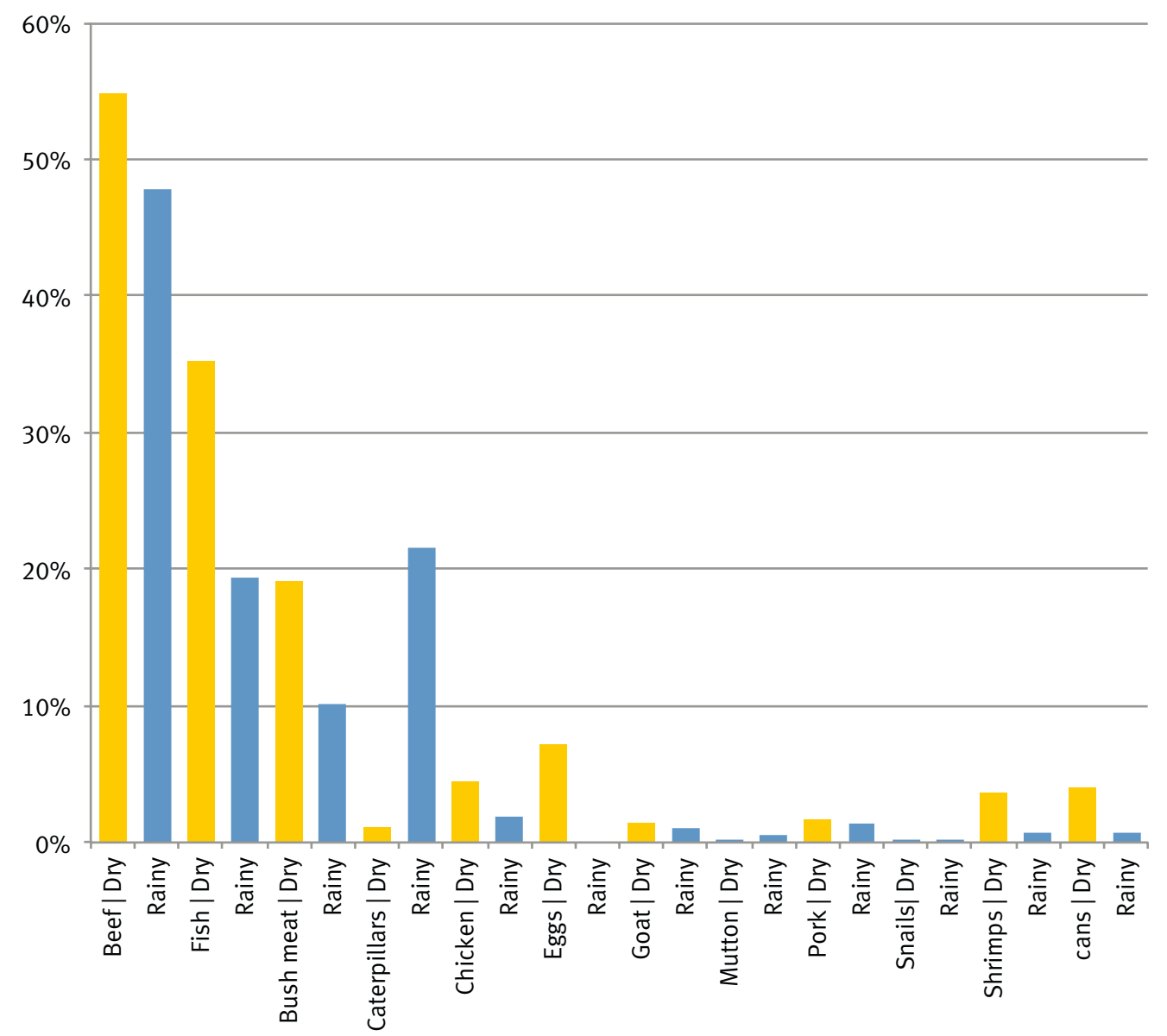

Figure 2.

Ranking of animal proteins consumed in Bangui (Central African Republic) households from school surveys conducted in March (dry season) and August (rainy season) 2006. The overall number of respondents exceeds the total number of respondents because of multiple-choice responses.

\section{Household expenses}

The household expenses survey $(n=1,000)$ showed similar trends in protein consumption (figure 3). In household expenses, domestic livestock sources weighed most heavily ( $50 \%)$, followed by fish $(24 \%)$, and bushmeat ( $22 \%$ ), of which $17 \%$ was smoked meat. Other sources of animal protein, such as shrimp, caterpillars, eggs, canned food, snails and other small items, represented only $2 \%$ of total expenses (figure 3).

\section{Bushmeat consumption in Bangui}

We used the household expenses survey to estimate the annual bushmeat consumption in Bangui. From the household expenses survey $(n=1,000)$, the total expenses of the households in a period of 7 days were 503,350 XFA (CFA

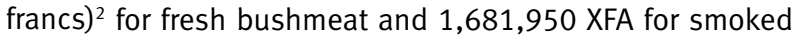
bushmeat. With an average household size of 9 members, the individual daily expense was estimate at 35 XFA.

Daily consumption was calculated by using the mean price of bushmeat $(2,000 \mathrm{XFA} / \mathrm{kg}$ for fresh bushmeat and $2,800 \mathrm{XFA} / \mathrm{kg}$ for smoked bushmeat, equivalent to $1,120 \mathrm{XFA} / \mathrm{kg}$ of fresh biomass). This calculated estimated

$21 \mathrm{XFA}=0.001524490$ Euros an annual bushmeat consumption of $10.22 \mathrm{~kg}$ of fresh biomass per capita. With a population of 800,000 (Kanda, 2005), the annual consumption of bushmeat in Bangui was estimated as 8,124 tonnes of fresh biomass, amounting to 10,124 billion XFA (table I).

\section{Prices of animal proteins}

\section{Availability and prices of alternative proteins}

A diverse range of animal proteins was on sale in both markets, including fresh and smoked products (table II). Smoked proteins (bushmeat, fish, caterpillars), when considering their protein content, were always significantly cheaper than fresh proteins by an average of approximately 1,000 XFA for one kilogram of equivalent fresh biomass. Among fresh proteins, poultry and other sources of protein were the costliest proteins available on the market. Fresh bushmeat and fresh fish always cost the same as or more than beef and ranked in the medium price range. Caterpillars were the cheapest fresh protein on the market in the rainy season. Interestingly, if the price of small piles of smoked bushmeat remained stable $(1,000-2,000 \mathrm{XFA} / \mathrm{kg})$, their size varied during the study period, which was convenient for poor consumers. 


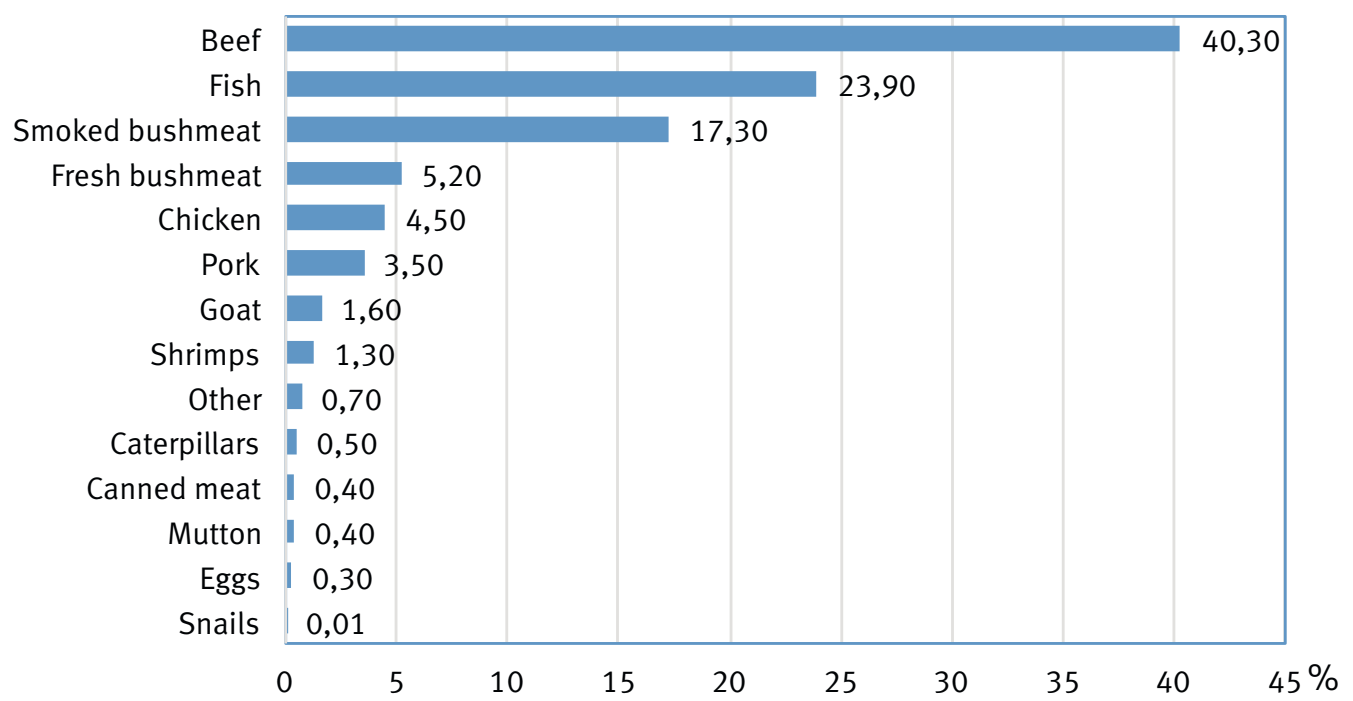

Figure 3.

Distribution of household expenses among Bangui (Central African Republic) consumers $(n=1,000)$ according to bushmeat consumption in Bangui.

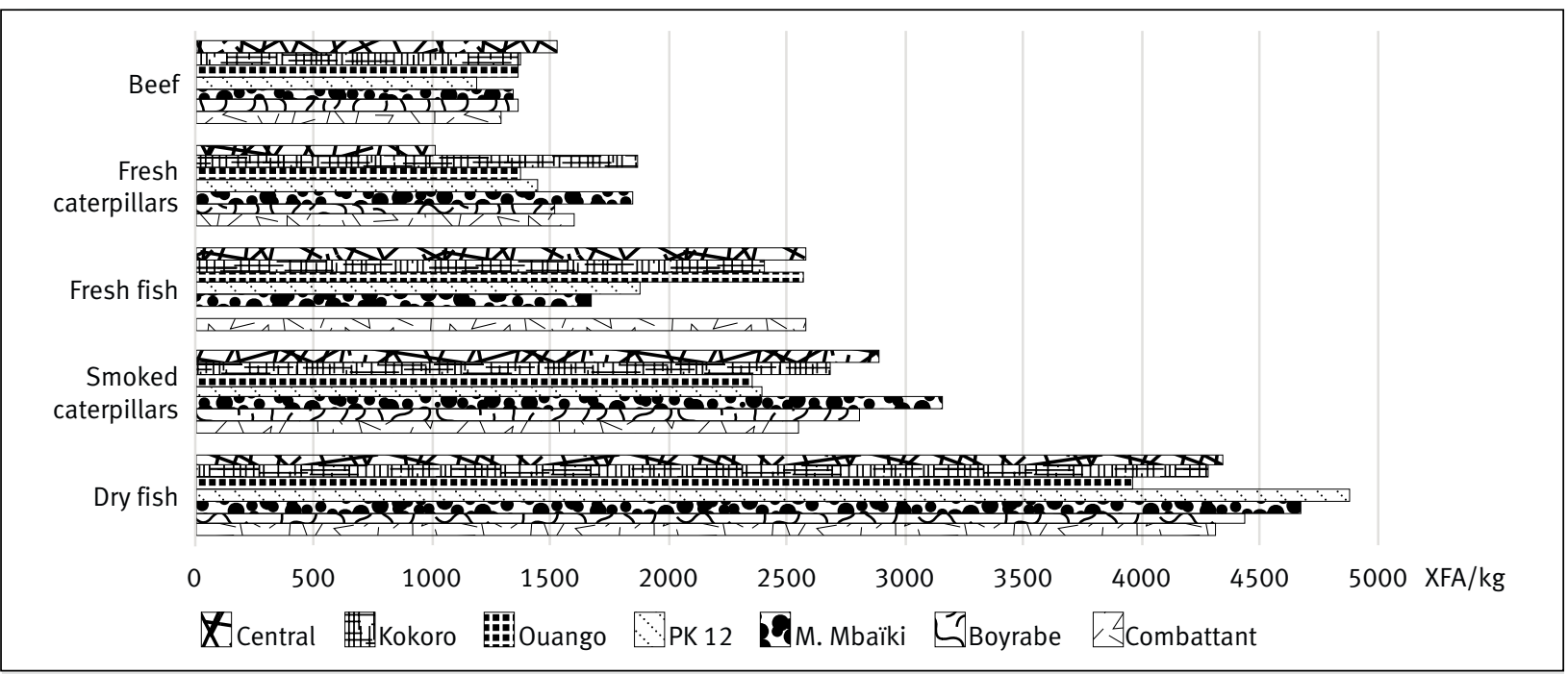

Figure 4.

Ranking of alternative animal protein prices in the Bangui (Central African Republic) markets from 2005-2008.

\section{Market location and prices of animal proteins}

The prices of alternative proteins (beef, fresh fish, smoked fish, fresh caterpillars, smoked caterpillars) were homogenous inside each protein group throughout the Bangui markets (figure 4), with the exception of beef, which was significantly more expensive in the Central market $(F=6.04$, $p<0.05, d f=3, n=44)$. The Central market was the more expensive market, and the PK-12 market was the cheapest market, with exception of dry fish. The observed differences were not significantly different.

\section{Market location and prices of bushmeat}

The pricing of bushmeat was investigated by using blue duiker species as an indicator of overall trends. The prices of fresh blue duiker meat were very similar between the PK-12 market $(1,980 \pm 431 \mathrm{XFA} / \mathrm{kg}, \mathrm{n}=17)$ and the PK-5 Kokoro market $(1,779 \pm 441 \mathrm{XFA} / \mathrm{kg}, \mathrm{n}=22)(\mathrm{p}>0.05)$. Overall, the prices of whole smoked blue duiker were in the same price range in the Bangui markets, ranking from 2,221 $\pm 335 \mathrm{XFA} / \mathrm{kg}$ in the PK-12 market to $2,890 \pm 251 \mathrm{XFA} / \mathrm{kg}$ in the Combattant market.

\section{Wildlife species and prices of bushmeat}

The taxonomic composition of the bushmeat on sale consisted mainly of common wildlife species, such as wild African grasscutter (Thryonomys swinderianus), warthog (Phacochoerus africanus aethiopicus), bushbuck (Tragelaphus scriptus), black-fronted duiker (Cephalophus nigrifrons), blue duiker (Philantomba monticola), small primates and snake. Meat from large ungulates, such as buffalo (Syncerus caffer), waterbuck (Kobus ellipsiprymnus) 
Table I.

Estimation of consumed bushmeat in Bangui. The equivalent fresh biomass quantities of smoked bushmeat are indicated in parenthesis.

\begin{tabular}{|c|c|c|c|c|c|}
\hline & $\begin{array}{c}\text { Expenses } \\
\text { XFA/capita/day }\end{array}$ & $\begin{array}{l}\text { Consumption } \\
\text { g/capita/day }\end{array}$ & $\begin{array}{l}\text { Consumption } \\
\mathrm{kg} / \text { capita/year }\end{array}$ & $\begin{array}{c}\text { Sales } \\
\text { millions XFA/year }\end{array}$ & $\begin{array}{l}\text { Equivalent fresh biomass } \\
\text { Consumption ( } T / \text { year) }\end{array}$ \\
\hline Fresh bushmeat & 8 & 4 & 1.46 & 2,328 & 1,164 \\
\hline Smoked bushmeat & 27 & $\begin{array}{l}9.6 \\
(24)\end{array}$ & $\begin{array}{c}3.50 \\
(8.76)\end{array}$ & 7,796 & $\begin{array}{c}2,784 \\
(6,960)\end{array}$ \\
\hline $\begin{array}{l}\text { Total equivalent } \\
\text { fresh biomass }\end{array}$ & 35 & 28 & 10.22 & 10,124 & 8,124 \\
\hline
\end{tabular}

Table II.

Prices of bushmeat and alternative sources of proteins in two major markets of Bangui (PK-12 and PK-5 markets) from 2005-2008. The values of smoked meats are provided in terms of equivalent fresh biomass.

Smoked proteins

Small piles of bushmeat

Bushmeat - whole animal

Fish

Caterpillars ${ }^{\star \star \star}$

Bushmeat in pieces

Fresh proteins

Other sources

Poultry

Fish

Bushmeat in pieces

Bushmeat - whole animal

Deboned beef

Beef offal

Beef with bones

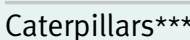

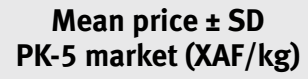 \\ Mean price \pm SD \\ PK-5 market (XAF/kg)}




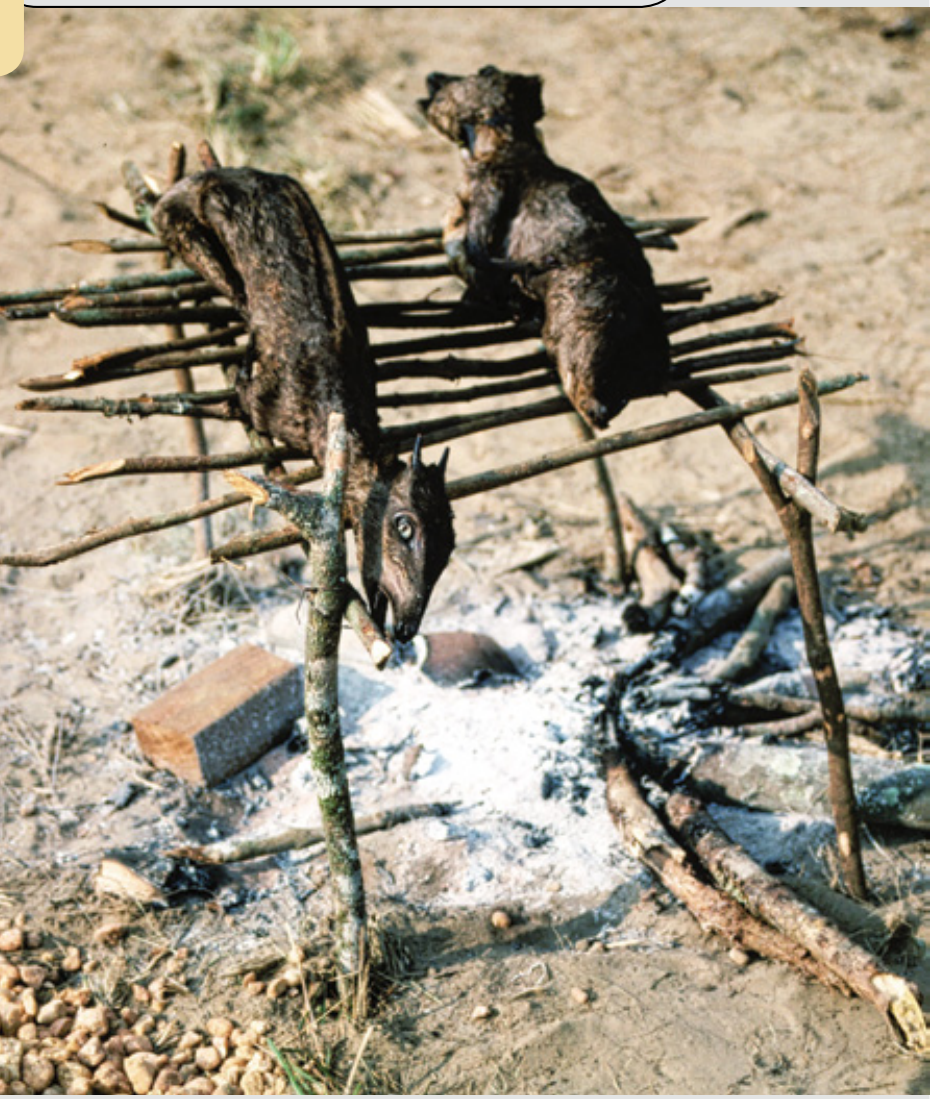

Photo 2.

Barbecue of blue duiker.

Photo C. Doumenge.

non-defined religion (2\%). Ethnic groups were dominant by Yakoma (28\%), followed by Gbaya (25\%), Mandjia (19\%), Banda (11\%), Oubangien, diverse and non-defined (5\%), Sara (4\%), foreigners (3\%), Zandé/Nzakara (3\%), Mboum (1\%) and Foulbé (0.5\%). The ethno-religious characteristics of the samples differed slightly from those of previous surveys ${ }^{3}$. However, in the context of Bangui's ongoing politico-ethnic crises and security issues occurring at the time of the survey, it was assumed that our sample showed a fair picture of the city population.

\section{Religion, ethnicity and bushmeat consumption}

There was no difference in bushmeat consumption (fresh and smoked) between Catholics (37 XFA/capita/day), Protestants (39 XFA/capita/day), and other religion (45 XFA/ capita/day). However, Muslim and Jehovah's Witnesses households consumed significantly less bushmeat than did households with other religious affiliations, with 4 XFA/ capita/day and $13 \mathrm{XFA} /$ person/day $(F=10.34, p<0.01$, $\mathrm{df}=4, \mathrm{n}=999$ ), respectively.

The amount of purchased bushmeat was not different among ethnic groups, except for the Foulbé, who are an Islamic group. In the Foulbé households, there was no bushmeat consumption $(n=9)$, although the sample size was too small to be statistically conclusive.

3 http://www.stat-centrafrique.com/Donnees/donnees\%20 structurelles/demographie/population\%20prefecture.htm

\section{Household wealth and bushmeat consumption}

Among the 1,000 surveyed households, the 100 wealthiest households were compared to the 100 poorest households, which were determined based on the declared income indicator.

Based on the income indicator, individual total daily expenses were higher for wealthy households (668 XFA) than for poor households (109 XFA). Wealthy households consumed more total bushmeat than poor households, $71 \pm 63 \mathrm{XFA} /$ capita/day versus $11 \pm 12$ XFA/capita/day $(n=100 ; t=9.35$, $p<0.01$ ), respectively. The consumption of fresh bushmeat was significantly higher among the wealthiest households than the poor households, at $21 \pm 34 \mathrm{XFA} /$ capita/day versus $0.7 \pm 3$ XFA/capita/day $(t=5.89, p<0.01, n=100)$, respectively. Likewise, wealthier households consumed more smoked bushmeat than poor households, at $50 \pm 49$ XFA/ capita/day versus $10 \pm 11$ XFA/capita/day $(t=7.81, p<0.01$, $\mathrm{n}=100)$, respectively.

Interestingly, the relative contribution of total bushmeat to purchased animal protein (figure 5) was slightly higher in poor households (24\%) than in wealthy households (19\%). Similarly, the relative contribution of smoked bushmeat to total animal protein purchases was higher in poor households $(22 \%)$ than in wealthy households, where the contribution of smoked bushmeat represented $12 \%$ of the total protein purchases. Overall, the contribution of fresh bushmeat was meagre in poor households, at only $2 \%$ of food purchases.

\section{Discussion}

\section{Bangui: a vigorous urban market for the supply of animal protein}

Africa is currently facing unprecedented demographic change that will greatly affect the world population. In 1950, Africans accounted for only $9 \%$ of the world's population. By the end of this century, however, approximately $40 \%$ of all people in the world, of which nearly half are children, will be African (Haub et al., 2011). By 2050, the population of Africa is projected to increase to 2.4 billion from 1.1 billion today (Population Reference Bureau, 2014). In addition, urbanization will continue accelerating, and it is estimated that approximately $70 \%$ of the world's population will be urban (FAO, 2009). Meanwhile, with increased revenue and more liberal economies, African society will evolve and modify the trade of food products and the organization of the market.

In central African countries, wholesale and retail markets supply the vast majority of the urban population with both food and manufactured products. This is the case in Bangui, where a vast network of markets provides urban consumers with necessary food products. Our observations revealed that the Bangui market provides a diverse supply of animal proteins throughout the year, including domestic meat (beef, goat, mutton, chicken, pork) and wild products, such as fish, bushmeat, and caterpillars. In our study, the taxonomic composition of bushmeat consisted mainly of common wildlife, such as small ungulates, small monkeys, and rodents that are generally less sensitive to hunting 


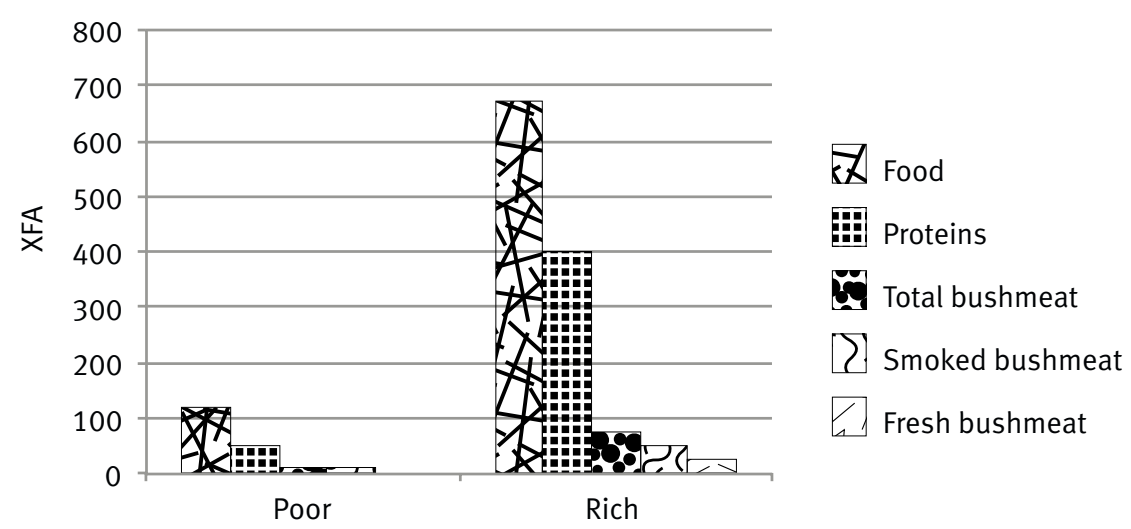

Figure 5.

Profiles of food purchases in XFA for wealthy and poor households in Bangui

(Central African Republic) based on daily expenses $(n=200)$.

pressure. This result was in accordance with previous observations of bushmeat carcasses sold in urban markets in West and Central Africa (Van Vliet et al., 2012; Mbete et al., 2011). However, elephant was also sometimes recorded in the market stalls. Nevertheless, for a better understanding of the functionality of this commodity chain, future studies could focus on how hunters adapt their practices to fit with the demands of such a vigorous urban market.

Bushmeat could be found fresh, but it was mainly available as wood-smoked dried in the Bangui markets. The presence of smoked products in the market is in accordance with the constraints of poor facilities for conserving and transporting meat. There was no frozen meat in the Bangui markets due to near non-existence of a cold chain. This differs from the situation in Gabon, where most of the meat is sold fresh (Steel, 1994; Starkey, 2004; Okouyi, 2006) or is defrosted before sale (Van Vliet, 2012). Carcass price was principally associated with the meat process, with little evidence that taxonomic group affected price, except in the case of elephant meat, which appeared to be a luxury meat; further investigation on consumer preferences is needed to understand why elephant meat was an exception. Typically, the condition of the carcass, whether wood-smoked dried or fresh, influenced prices. In addition to caterpillars, smoked products (bushmeat, fish), when taking into account the protein content, were always the least expensive sources of animal protein in the urban market, making bushmeat a normal or even inferior good. Caterpillars were always the cheapest protein, but they were only available in the rainy season. These results revealed that in Bangui, smoked bushmeat is not a luxury product, but rather a common product sold at a low price year-round, sometimes at three times less than the price of small livestock meat. This result was in accordance with observations made in Kisangani, DRC by Van Vliet et al. (2012). However, this conclusion is challenged by other studies that found bushmeat to be a luxury item for the urban population (Macdonald et al., 2012; Pailler, 2007). In Takoradi, Ghana, bushmeat was described as a luxury or superior good by Cowlishaw et al. (2005).
There was no evidence of a seasonal effect on market prices of animal proteins, apart from the availability of products, such as caterpillars, which are a very cheap protein that is well appreciated by Central African consumers. Fresh proteins (livestock, bushmeat and fish) were the most expensive animal proteins available on market. The pattern of relative prices in the supply of fresh animal proteins revealed that small-farmed proteins (poultry, goat, mutton and pork) were the costliest proteins, while beef was relatively affordable in comparison to fresh fish and fresh bushmeat. This difference might be linked to the existence of farmers' organizations (Mbetid-Bessane et al., 2010), such as the National Federation of Central African Farmers for Cattle (FNEC). In contrast, the small livestock sector is not as well organized, which may be due to small livestock being reserved for specific ceremonies and social exchanges (Fargeot, 2013). There was little difference between the average price of fresh beef and smoked bushmeat, which is congruent with the market profile of alternative proteins.

Additionally, these observations highlight how the market adjusts to meet the needs of poor consumers. The price of small piles of bushmeat was constant year round, while the size varied, suggesting that seasonal price differences in the market could reflect the seasonality of the trade. Similarly, overall prices were higher in the Central market, which was situated in the wealthiest areas of Bangui, while the PK-12 market offered better prices, as expected for a wholesale market. Bushmeat price was relatively homogenous throughout the capital but was highest in the Combattant market, which is known to have a competitive beef market.

\section{Determinants of bushmeat consumption in Bangui}

To explore the effect of income on bushmeat demand, we used household expenses as an indicator of urban consumption. First, the results showed that most Bangui households consumed bushmeat. Interestingly, in direct response to protein prices, Bangui household consumption 


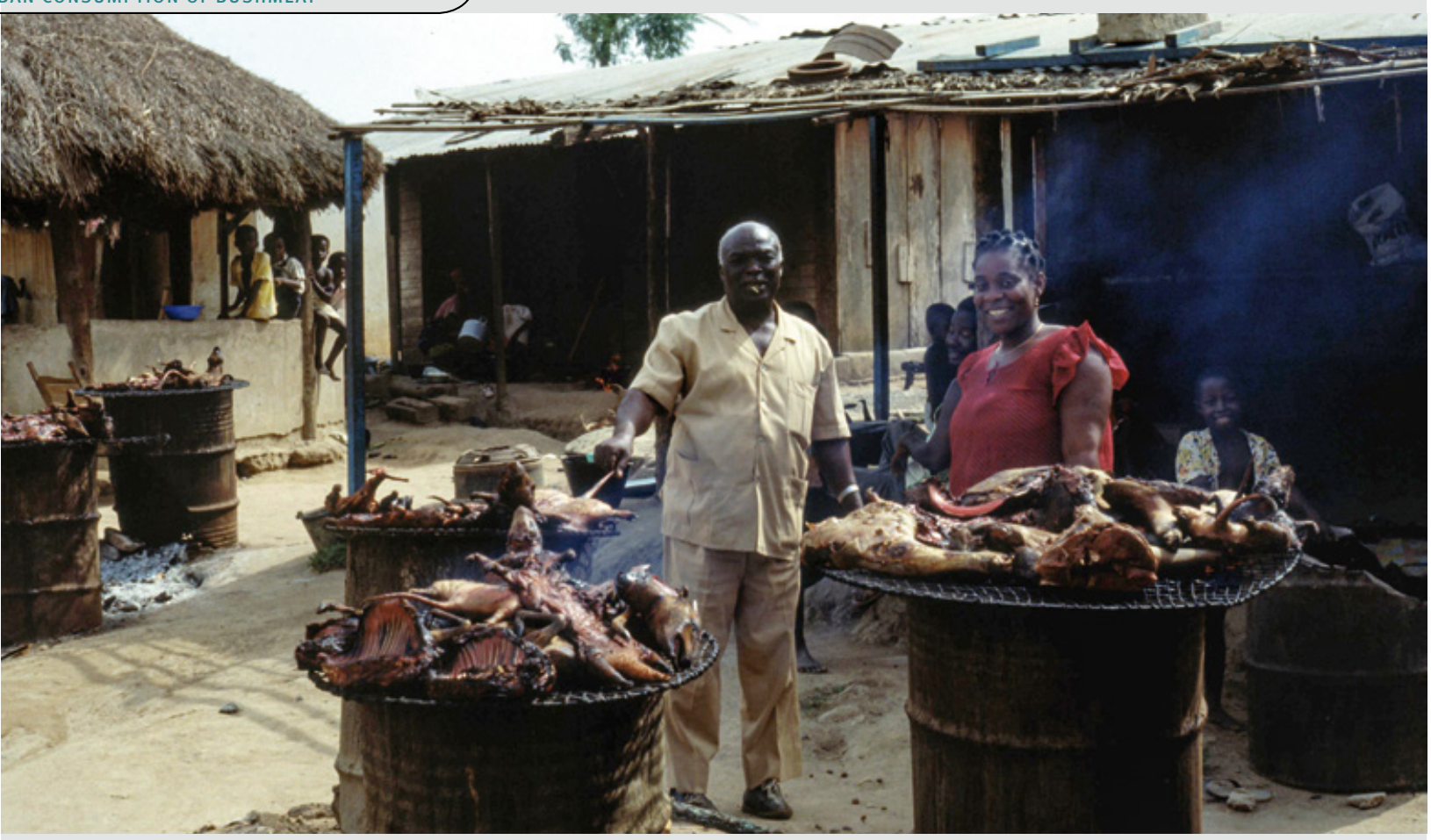

Photo 3.

Installation to smoke and sell the bushmeat on a market.

Photo R. Peltier.

was diversified by including several types of domestic and wild meat. As expected, clear differences appeared between consumption in wealthy and poor households. Animal protein intake was the highest in wealthier Bangui households. This observation is congruent with results from studies in other Central African countries (Wilkie et al., 2005; Fa et al., 2009). In addition, it confirms the expectation that wealthier households are less constrained than poorer households to meet their basic needs. Similarly, wealthier households consumed more bushmeat than did poorer households. It is particularly noteworthy, however, that the proportion of total protein intake made up by bushmeat was the highest for poor households. This result suggests that the low price of smoked bushmeat is linked to its availability in small portions, which allows low-income households to access proteins. Poor households consumed much more smoked bushmeat than fresh bushmeat; by contrast, wealthy households consumed large amounts of fresh bushmeat. Our study clearly shows that urban consumers are sensitive to prices and consequently choose the most affordable meat available on the market, as previously suggested (Bowen-Jones, 1997; Wilkie and Carpenter, 1999; Wilkie and Godoy, 2001). In that context, it is likely that demand for the cheapest source of protein is a major driver of bushmeat consumption for the poorest urban households.

It is clear that food choice is complex, and other factors beyond economic determinants might influence the consumer's choice. Bushmeat plays an important role in ceremonies and represents a link between the urban environment and the village (Chardonnet et al., 1995). Bushmeat is also frequently associated with cultural beliefs. Taste might also influence its consumption. In Gabon, Schenck et al. (2006) emphasized that only rural consumers consistently prefer bushmeat over alternatives. In their study, Van Vliet et al. (2012) concluded that the price of bushmeat was not necessarily linked to availability but could also reflect preferences. Similarly, in our study, we found that religious-cultural values affected the consumption of bushmeat. Bushmeat consumption was near absent in Muslim and Jehovah's Witness households. Similarly, the Foulbé people, who practise Islam, excluded bushmeat from their diet. However, these findings should be viewed in the context of the urban Bangui population, in which Christians form the largest majority.

\section{Conclusion}

This study confirms the importance of bushmeat in urban population food. Bushmeat is likely to contribute to a better balanced diet and the food security of poor households (Fargeot, 2013). However, unlike rural populations, who mostly depend on wild products to meet their daily requirements (Nasi et al., 2011), the urban consumer has a larger choice among alternative animal proteins. With high urbanization rates in sub-Saharan Africa and the improved standard of living of urban populations, the demand for total meat protein is rising. However, changes in consumption patterns are likely. According to economic principles, increased income would lead to decreased bushmeat demand and higher demand for more luxurious substitutes, such as alternative products from the domestic sector. As noted by other authors (Fa et al., 2009; Van Vliet et al., 2012), however, we recommend caution when extrapolating the data of bushmeat consumption from rural areas to cities. The patterns of consumption are likely different, particularly when predicting trends in bushmeat consumption and wildlife harvest. 
Given the importance of feeding growing urban African populations in the coming years, there is a need to identify key indicators for long-term monitoring of markets and household consumption. Household consumption and market price surveys could be easily adapted to a large scale and operated at a low cost. Indicators related to issues of supply and demand could help inform authorities and support strategies for meeting food supply and biodiversity conservation objectives, which can be adapted by the State. Complementary studies aimed at understanding trade dynamics should also consider the condition of the resource base (wildlife survey) and hunter behaviour.

\section{Acknowledgments}

The Ministry of the Environment, Water Resources and Forestry of the CAR are kindly acknowledged for providing us with the opportunity to conduct this research. This study was associated with the "Projet de Gestion des Terroirs de Chasse villageoise", which is co-funded by the French Global Environment Facility/Fonds Français pour l'Environnement Mondial (FFEM) and the Fonds de Développement Forestier et Touristique de la République Centrafricaine (FDFT) under the supervision of the Ministry of the Environment, Water Resources and Forestry of the Central African Republic. This paper has benefited from the CGIAR CRP fund "Forest, Trees \& Agroforestry".

\section{References}

Asibey E. O. A., 1974. Wildlife as a source of protein in Africa South of Sahara. Biological Conservation, 6 (1): 32-39.

BennettE. L., Robinson J. G., 2000. Hunting of wildlife in tropical forests - implications for biodiversity and forest peoples. Environment Department working papers, no. 76. Biodiversity series. Washington, D.C.: The World Bank. http://documents.worldbank.org/curated/en/101611468780290485/ Hunting-of-wildlife-in-tropical-forests-implications-for-biodiversity-and-forest-peoples

Bennett E. L., 2008. Hunting and trade of bushmeat in Central Africa: a review of conservation, livelihood and policy implications. Washington DC, WCS, $37 \mathrm{p}$.

Bowen-Jones E., 1997. A review of the current depth of knowledge on the commercial bushmeat trade (with emphasis on central/west Africa and the great apes). Ape Alliance/ Flora and Fauna International, Cambridge.

Bowen-Jones E., Pendry S., 1999. The threat to primates and other mammals from the bushmeat trade in Africa, and how this threat could be diminished. Oryx, 33 (3): 233-246.

Chardonnet P., Chardonnet B., Daniel P., Darroze S., Feer F., Forster M., et al., 1995. Faune sauvage africaine : la ressource oubliée. Tome 1 : synthèse. Tome 2 : monographies. Luxembourg, Office des publications officielles des Communautés européennes, 2 vol., 704 p.
CBSNEWS, 2014. Ebola scares West Africans away from bush meat. October 292014 2:55 PM. http://www.cbsnews. $\mathrm{com} / \mathrm{news} / \mathrm{ebola-virus-scares-west-africans-away-from-}$ bush-meat/

Colyn M., Dudu A., Mbaele M., 1987. Data on small and medium scale game utilisation in the rain forest of Zaire. In Actes du Symposium international et de la conférence: Gestion de la faune sauvage en Afrique subsaharienne, Ed. Clers B. D., 6-13 octobre 1987, Harare, Zimbabwe, 109-141.

Cowlishaw G., Mendelson S., Rowcliffe J. M., 2005. Evidence for post-depletion sustainability in a mature bushmeat market. Journal of Applied Ecology, 42: 460-468.

Diéval S., 2000. La filière viande de chasse à Bangui, République Centrafricaine. Cergy-Pontoise, ISTOM, 211 p.

Docky J. H., 1987. Rapport d'enquêtes consommation viande de gibier à Bangui, République Centrafricaine. Octobre à décembre. Bangui, Ministère des Eaux, Forêts, Chasse, Pêche et Tourisme, $30 \mathrm{p}$.

Doungoupou G. M., 2005. Monographie de la ville de Bangui. Rapport d'analyse thématique. République Centrafricaine, Ministère de l'Économie, du plan et de la coopération internationale, Direction générale de la statistique, des études économiques et sociales, Bureau central du recensement, xxii, 96 p. https://searchworks.stanford.edu/ view/8441585

Dubresson A., Raison J. P., 1998. L’Afrique subsaharienne. Une géographie du changement. Paris, Armand Colin, Collection U-Géographie, 248 p.

East T., Kümpel N. F., Milner-Gulland E. J., Rowcliffe J. M., 2005. Determinants of urban bushmeat consumption in Rio Muni, Equatorial Guinea. Biological Conservation, 126: 206-215.

Fa J. E., Juste J., Perez Del Val J., Castroviejo J., 1995. Impact of market hunting on mammal species in Equatorial Guinea. Conservation Biology, 9 (5): 1107-1115.

Fa J. E., Currie D., Meeuwig J., 2003. Bushmeat and food security in the Congo Basin: linkages between wildlife and people's future. Environmental Conservation, 30 (1): 71-78.

Fa J. E., Albrechtsen L., Johnson P. J., Macdonald D. W., 2009. Linkages between household wealth, bushmeat and other animal protein consumption are not invariant: evidence from Rio Muni, Equatorial Guinea. Animal Conservation, 12: 599-610.

FAO, 2006. Hunting and Bushmeat. Nature \& Faune, 21 (1), $63 \mathrm{p}$.

FAO, 2009. How to feed the world in 2050. Rome, 35 p. http://www.fao.org/fileadmin/templates/wsfs/docs/ expert paper/How to Feed the World in 2050.pdf

Fargeot C., 2013. La chasse commerciale en Afrique centrale: une menace pour la biodiversité ou une activité économique durable ? Le cas de la République Centrafricaine. Thèse de doctorat, Géographie et aménagement de l'espace, Université Paul Valéry, Montpellier, 3 vol., 605 p., 120 p., 82 p. https://agritrop.cirad.fr/572003/1/document 572003.pdf 
Harrison R. D., 2011. Emptying the forest: hunting and the extirpation of wildlife from tropical nature reserves. Bioscience, 61 (11): 919-924.

Haub C., Gribble J., Jacobsen L., 2011. World Population Data Sheet 2011. Population Reference Bureau, Washington, 41 p. http://www.prb.org/pdf11/2011-world-population-data-sheet-presentation.pdf

Kanda T. B., 2005. Structure et répartition spatiale de la population. Rapport d'analyse thématique. $3^{\text {e }} \mathrm{RGPH}$. Bangui, RCA, Ministère de l'Économie, du Plan et de la Coopération internationale, $62 \mathrm{p}$.

Leroy E. M., Rouquet P., Formenty P., Souquière S., Kilbourne A., Froment J. M., et al., 2004. Multiple Ebola virus transmission events and rapid decline of central African wildlife. Science, 303 (5656): 387-390.

Luzietoso N., 1999. Marchés-portes de Kinshasa et relations villes/campagnes. Processus de standardisation alimentaire urbaine et organisation des activités agro-alimentaires : le cas des Fufu et des Kwanga à Kinshasa (RDC). Montpellier, Thèse Sciences économiques, 137-138.

Macdonald D. W., Johnson P. J., Albrechtsen L., Seymour S., Dupain J., Hall A., et al., 2012. Bushmeat trade in the Cross-Sanaga rivers region: Evidence for the importance of protected areas. Biological Conservation, 147 (1): 107-114.

Mbete R. A., Banga-Mboko H., Racey P., Mfoukou-Ntsakala A., Nganga I., Vermeulen C., et al., 2011. Household bushmeat consumption in Brazzaville, The Republic of the Congo. Tropical Conservation Science. 4 (2): 187-202

Mbetid-Bessane E., Kadekoy-Tigague D., Folefack D. P., Havard M., Enam J., Djondang K., 2010. L'émergence des organisations de producteurs en Afrique centrale. In : Savanes africaines en développement : innover pour durer, Eds. Seiny-Boukar et Boumard, avril 2009, Garoua, Cameroun. Cirad, 7 p. https://hal.archives-ouvertes.fr/ cirad-00471533v1/document

Nasi R., Taber A., Van Vliet N., 2011. Empty forests, empty stomachs? Bushmeat and livelihoods in Congo and Amazon Basins. International Forestry Review, 13 (3): 355-368.

Ndona G., 2003. Contribution du gibier dans la lutte contre la pauvreté et l'insécurité alimentaire (Kinshasa, RDC). CRESA bois, Yaoundé, 99 p.

Noss A. J., 1998. The impacts of cable snare hunting on wildlife populations in the forests of the Central African Republic. Conservation Biology, 12 (2): 390-398.

Ntiamoa-Baidu Y., 1987. La faune d'Afrique de l'Ouest : une ressource naturelle menacée. Unasylva, 39 (156): 27-35.

Okouyi J., 2006. Savoirs locaux et outils modernes cynégétiques : développement de la filière commercial de viande de brousse à Makokou (Gabon). Thèse, Université d’Orléans, France.

Pailler S., 2007. The necessity, complexity and difficulty of resolving the bushmeat crisis in west-central Africa. Journal of Development and Social Transformation, 99-107.

Peters H. P. J., 1993. Exploitation de la faune et développement rural en République Centrafricaine. Nature et Faune, 9 (1): 34-40.
Puit M., 2003. Étude de la commercialisation de la viande de brousse dans la région continentale Rio Muni, Guinée Équatoriale. Institut vétérinaire tropical, Liège, Université de Liège, $38 \mathrm{p}$.

Population Reference Bureau, 2014. World population data sheet. 20 p. http://www.prb.org/pdf14/2014-world-population-data-sheet eng.pdf

Redford K. H., 1992. The empty forest. BioScience, 42 (6): 412-422.

Rieu L., 2005. Étude du commerce et de la consommation de viande de brousse dans un centre urbain d'Afrique centrale. Berberati, République Centrafricaine, Bruxelles, Projet GEPAC, 75 p.

Rose A. L., 1996. The African forest bushmeat crisis. African Primates, 2: 32-34.

Schenck M., Nsame Effa E., Starkey M., Wilkie D., Abernethy K., Telfer P., et al., 2006. Why people eat bushmeat: Results from two-choice, taste tests in Gabon, Central Africa. Human Ecology, 34 (3): 433-445.

Starkey M., 2004. Commerce and subsistence: the hunting, sale and consumption of bushmeat in Gabon. Doctoral thesis, Department of Geography, Cambridge University, Cambridge, United Kingdom. https://www.repository.cam. ac.uk/handle/1810/251940

Steel E. A., 1994. Étude sur le volume et la valeur du commerce de la viande de brousse au Gabon. Libreville,Gabon, Ministère des Eaux et Forêts et de l'Environnement / WWF, $84 \mathrm{p}$.

Université Médicale Virtuelle Francophone, 2011. Méthodologie des enquêtes alimentaires ; Support de Cours. Collège des Enseignants de Nutrition, 28 p. http://campus.cerimes. $\mathrm{fr} /$ nutrition/enseignement/nutrition 14/site/html/cours. pdf

Van Vliet N., Nebesse C., Gambalemoke S., Akaibe D., Nasi R., 2012. The bushmeat market in Kisangani, Democratic Republic of Congo: implications for conservation and food security. Oryx, 46 (2): 196-203.

Weber J., 1995. Gestion des ressources renouvelables : fondements théoriques d'un programme de recherche. Cirad, $21 \mathrm{p}$.

Wilkie D. S., Carpenter J. F., 1999. Bushmeat hunting in the Congo Basin: an assessment of impacts and options for mitigation. Biodiversity and Conservation, 8 (7): 927-955.

Wilkie D. S., Godoy R. A., 2001. Income and price elasticity of bushmeat demand in lowland Amerindian societies. Conservation Biology, 15: 761-769.

Wilkie D. S., Abernethy K., Effa E. N., Telfer O., Godoy R., 2005. Roles of prices and wealth consumer demand for bushmeat in Gabon, Central Africa. Conservation Biology, 19 (1): 268-274.

Yamalé S., 2006. Observations techniques et analyse des échantillons biologiques dans le cadre du suivi économique d'un gros marché urbain des viandes de chasse à Bangui : cas de PK 12 Bégoua. Bangui, ISDR, 51 p. 